\title{
AGILE ORGANIZATIONAL MODEL FOR MANAGING LOCAL GOVERNMENT PROJECTS
}

Scientific paper / Znanstveni rad

Diana Car- Pušić

(Received: 05 February 2019; accepted: 28 May 2019)

University of Rijeka, Faculty of Civil Engineering, Full Professor

Corresponding author: diana.car.pusic@uniri.hr

Ivan Marović

University of Rijeka, Faculty of Civil Engineering, Assistant Professor

Goran Bulatović

Exprimo d.0.0., mag.ing.aedif.

\begin{abstract}
Local self-government units often consider project management as an accompanying activity and therefore do not accord it the appropriate level of importance. The term "agile" refers to a series of methods developed for more flexible project management. Thus, the background of an agile concept and its content are presented in this paper. Furthermore, the concept is compared with traditional project management methodologies. However, a priori implementation of agile-based model in an unrealistic solution can cause more damage than good. Hence, this paper proposes an agile-based matrix organizational model that adapts to the needs and particularities of the work environment in which it implemented, especially the various activities of government bodies. The model will define a new and flexible management structure for local self-government units based on the development of human resources, constant change of culture, and regular activities of government bodies, thereby improving their reliability and effectiveness.
\end{abstract}

Keywords: organizational structure; agile organizational model; local government; Scrum method; project management

\section{AGILE ORGANIZACIJSKI MODEL U UPRAVLJANJU PROJEKTIMA U LOKALNOJ UPRAVI}

Sažetak: Jedinice lokalne samouprave često tretiraju upravljanje projektima kao prateću aktivnost, zbog čega mu se ne pridaje važnost koju zaslužuje. Izraz Agile odnosi se na niz metoda razvijenih radi fleksibilijijeg upravljanja projektima. U radu je objašnjeno porijeklo nastanka koncepta Agile i definiran je njegov sadržaj. Provedena je usporedba s tradicionalnim metodologijama upravljanja projektima. Međutim, ističe se da a priori provedba, u neodgovarajućim okolnostima, može prouzročiti više štete nego koristi. Upravo je to razmišljanje potaknulo prijedlog modela organizacije zasnovanog na načelima Agilea, koji bi se prilagodio potrebama i specifičnostima radnog okruženja u kojemu se provodi, osobito u svjetlu raznovrsnih aktivnosti tijela uprave. Svrha modela je definiranje nove, fleksibilne upravljačke strukture u jedinicama lokalne samouprave, koja će se temeljiti na razvoju ljudskih resursa i stalnoj promjeni kulture, ne zanemarujući redovite aktivnosti tijela uprave, nego čineći in pouzdanim i učinkovitim.

Ključne riječi: organizacijska struktura; Agile organizacijski model; lokalna uprava; Scrum metoda; upravljanje projektima 


\section{INTRODUCTION}

It is a widely accepted fact that local governments in the Republic of Croatia do not rapidly solve public affairs in most of their areas of work. The processes are overly complicated, which hinder economic development. Thus, a series of goals has been set in the proposal of the Public Administration Development Strategy for 2015-2020, some of which are outlined as follows [1]:

- Increase in efficiency and effectiveness in the public sector,

- Increase in the quality of public services,

- Increase in trust between the public sector and the end users regarding electronic communication,

- Higher degree of openness, transparency, and accessibility of public bodies towards the public,

- Use of modern ICT technologies for effective service provision and higher transparency of government bodies,

- Integration with the European government area,

The challenge is to develop a model compatible with the existing regulatory restraints in the Republic of Croatia that is applicable within the framework of local self-government units (LSGU). Thus, agile methodologies discussed in this work present a valid tool for realizing the general goals listed above. However, it is necessary to understand where these methods originate from and analyze their effectiveness within the given framework. Meanwhile, agile approaches have their pros and cons just as the traditional approaches of project management. Hence, an a priori implementation in an unrealistic solution can cause more damage than good. This is the rationale behind the proposal of a new and improved model that would adapt to the needs and particularities of the work environment it is implemented in, especially the various activities of government bodies ranging from administrative to professional duties. However, there is an increasing number of professional activities related to the LSGUs participation in the projects whereby construction projects such as communal infrastructure projects and social standard projects are highlighted. This is a result of efforts to meet a number of public needs as well as increase investment activity, thereby increasing GDP rate. Local authorities are increasingly trying to take advantage of the possibility of financing these projects with EU funds and thus expect greater investments in public projects. Meanwhile, the realization of utility infrastructure projects is often necessary for further investments in public and private facilities. Therefore, the proposed model will aim at defining a new, flexible, and management structure for LSGU, based on the development of human resources, constant change of culture, and the regular activities of such bodies, thereby improving their reliability and effectiveness.

Mao et al. [2] emphasized that a careful organizational structure paves way for the success of a construction project by fostering a strong and lasting organizational culture. Their research employed field theory to demonstrate the development of organizational culture, thereby resulting in a novel model for identifying the effect of organizational structure on the formation of organizational culture in a construction project. As highlighted by Dobbs et al. [3], a well-designed project organization is conducive to the integration of stakeholders, thereby resulting in a $12 \%$ reduction in capital expense. Therefore, in organizations dealing with publicly funded projects, it is of utmost importance to manage stakeholders particularly carefully. Bider and Jalali [4] discussed what is needed to implement the agile approach, and in which business situations the agile approach is the most appropriate. Meanwhile, they formulated a theoretical framework based on Nonaka's SECI model [5], where SECI represents Socialization-Externalization-Combination-Internalization. It explains the ways in which knowledge is created in an organization and its transformation from a tacit form to an explicit form and vice versa. Bider and Jalali [4] concluded that a difference exists between agile and non-agile business process developments. They also proposed an agile implementation framework based on three questions: why, how, and when. The approach enabled them to understand the risks and requirements involved in a particular process development strategy. On the other hand, Demir and Theis [6] demonstrated how agile project management and Scrum approach can increase coordination, interface management, collaboration, and transparency in all project construction phases. They emphasized how traditional waterfall model of project management [7] consists of a sequential process in which the scheduler or planner forecasts all activities prior to the start of the project, thereby resulting with evaluations at the end of each phase of the project. Hence, the approach is not suitable for managing tasks in the early stages of the projects due to its dynamic environment. On the other hand, Owen et al. [8] developed an agile design management approach based on agile initial concepts, to manage construction projects during the design phase. Meanwhile, Demir and Theis [6] concluded that an agile approach during the design phase in construction project management is better Car-Pušić, D, Marović, I, Bulatović, G 
than the traditional approach, especially when projects have to deal with risk and uncertainty, fast-track projects and projects with a strong link between design and execution. Regarding the use of agile approach in public administrations, Torrecila-Salinas et al. [9] concluded that agile can be effective for certain projects in public administration, especially short projects and projects with more experienced teams.

The purpose of this research is to develop an organizational model for LSGU suitable for project management and management change within the organization. Particularly prominent is the project management department which functioning in the proposed innovated model has been described.

\section{RESEARCH TASKS AND METHODOLOGY}

The main idea behind the proposed agile-based matrix organizational model is the restructuring of the organizational scheme from a functional type to a more flexible type, by adopting a series of management principles based on a common concept called agile. This model aims to combine functional and project (or matrix) elements of management within the organizational structure with the agile-based project management department. The measures and recommendations regarding the model implementation are also provided.

Based on the set goals, three main research tasks were defined:

- Identify the present state and problems in the existing local government management scheme of the Republic of Croatia in relation to project development,

- Establish important differences between agile concept and traditional project management,

- Based on the established facts, propose the basis of improved management model for local government units that supports project development.

The bases for obtaining an adequate amount of information to develop an improved LSGU management model that adequately supports project implementation are:

- Analysis of the legal framework regulating LSGU management in the Republic of Croatia,

- Analysis of references dealing with agile methods and comparison with traditional project management methods,

- Identification of problems by interviewing two deputy mayors and heads of departments (i.e. procurement, financing, and planning department) in the management systems of LSGUs, data analysis and structuring.

Based on the bases listed above, an improved basic management model will be proposed for the implementation of projects, using basic agile framework.

\section{OVERVIEW OF THE PRESENT STATE IN THE AREA}

\subsection{Present state in local and regional governments in the Republic of Croatia}

The organizational management framework and operation of LSGU are largely determined by positive legal regulations. Despite the legal framework, there is a possibility of improvement that often depends on human factor, especially at higher management levels. Thus, a preference for personal leadership style, professionalism, responsibility, and professional competence have a significant influence. Meanwhile, current opportunities and especially Croatia's accession to the EU require a more agile adaptation to changes as an integral part of the process and their adequate management. Particularly, the need for change is due to the increasing level of digitization in EU countries and beyond, and the real competitive lag in digitization of the Republic of Croatia in comparison with the European average. However, the existing LSGU structure does not correspond to the required and expected changes, thereby necessitating modification [10].

Local and regional self-governments in the Republic of Croatia are structured and functionally defined primarily by the Law on Local and Regional Self-Government [11], subsequently referred to as the Law. This Law defines the self-governing area of municipalities, cities, and counties, and primarily deals with issues of meeting citizens' needs such as housing and housing planning, spatial and urban planning, communal economy, social welfare, education, environmental protection, traffic, issuance of necessary regulations regarding building construction, etc. It should be emphasized that there are some self-governing activities that local and regional selfgovernment units are obliged to perform and some activities that are regulated by special laws. Furthermore, there

Car-Pušić, D, Marović, I, Bulatović, G 
are administrative and professional affairs within the self-governing sphere, which is an important factor for the development of a new organizational model. To carry out tasks from the self-governing area of local and regional self-government units, administrative departments and departments (administrative bodies) are established based on the Law.

However, it is important to specify the most important provisions of the Regional Development Act of the Republic of Croatia [12], subsequently referred to as the Act. The Act aims to regulate the objectives and principles of regional development management and provide conditions for the most efficient use of EU funds, especially the European Regional Development Fund. The basic principles of regional development policy that the Act promotes are strategic planning by adopting, implementing, and monitoring the implementation of multi-annual planning documents of regional sustainable development prescribed by the provisions of this Law. In principle, planning and development should be carried out through partnership and co-operation of regional units with state administrative bodies, scientific institutions, economic entities, and civil society organizations. Thus, regional development can be financed by combining financial resources from various sources, especially through development and economic projects. Moreover, LSGU creates adequate conditions for its own development and better alignment with the regional development guidelines through possible forms of participation and active involvement in regional development (strategic planning of the development of counties and urban areas) and through active and effective participation within the legal institutional framework (such as regional councils as well as regional and local development agencies). A special form of association permitted by the Law is the inclusion of LSGU into urban agglomerations and urban areas for joint strategic planning, withdrawal of financial resources from EU funds as well as the implementation of planning documents through project implementations. However, this possibility has not been sufficiently exploited in practice. Meanwhile, these principles and provisions are relevant to the proposed hybrid model and should be considered and used in the best and most effective way in future developments and implementations of the model.

In the Republic of Croatia, the Public Administration Development Strategy for 2015-2020 [1] was adopted in 2015 , subsequently referred to as the Strategy 2015-2020. The state of public administration was analyzed based on three basic categories: public services, human resources, and public administration system.

The following problems have been identified:

- Provision of public services - Problems primarily refer to the complexity and slowness of public administration,

- Human resources in public administration - Problems refer to unnecessarily complicated processes encumbering the system and the lack of competent standards,

- Public administration system - irrationality, fragmented authority in the system of local self-government, and corruption.

However, problems from all these segments have been identified In LSGUs, which are part of the public administration system. These are the reasons for the necessary changes and the basis for the development of a new, agile-based improved model.

\subsection{Agile concept and its application in project management in comparison with traditional project management}

The basic ideas of the agile concept are summarized in Agile Manifesto [13]. Basically, it is the approach of accepting change as an inevitable and flexible adaptation of the system to them. This concept is supported by cyclic iterative approach. Therefore, as one of the basic values of the Agile Manifesto, reaction to changes should be indicated before the plan is further developed. This is an advantage for individuals and their interaction with processes and tools. Moreover, the advantage is contributed to the work documentation rather than the comprehensive documentation, based on cyclic approach. Hence, agile approach has a rational and working behavior as opposed to a traditional and planned approach that seeks information comprehensiveness [10]. Since the "agile" is characterized by a described way of thinking, a number of methods which were adapted to the requirements of specific business environments and requirements have been developed, primarily in the IT industry. All these methods are characterized by the same generic properties, e.g. continuous planning, collaboration within workgroups, frequent testing, and delivery in iterations. The use of agile methods achieves more flexibility or "the ability to both create and respond to change in order to profit in a turbulent business environment," as Owen et al. [8] stated. Moreover, the agile concept are also mapped to the area of project management. Meanwhile, a kind of

Car-Pušić, D, Marović, I, Bulatović, G 
rigidity exists in traditional project management, which arises from the need to pre-define all requirements for efficient control of the project course strictly defined by requirements, costs, and time. A well-known management triangle points to the basic, commonly accepted limitations in the project. In traditional approaches, project requirements as well as the costs and premises for meeting these requirements are predominantly the main limiting factors. Consequently, the project is characterized by a kind of rigidity and an effort to control the project flow as strictly as possible. However, pre-definition of requests result in frequent overrunning of time or cost, or often both. As the focus is to satisfy project requirements, the value of delivery is often neglected. Cobb [14] supported this statement, asserting that "... greater than 50 percent of project that had successfully met their cost and schedule goals failed to deliver the business value that was intended."

The agile approach considers variability of both the environment and the project requirements. However, it focuses on defining the requirements by priorities and interdependencies, thereby limiting the costs and time needed to meet the requirements. The goal is to deliver the maximum possible value within the given limits. Cobb [14] maintained a "... stronger focus on producing value for the customer ... it is understood and expected that the customer is going to introduce changes throughout the project to try to optimize the business value the project produces." Thus, "agile" has been replaced by "customizable," as opposed to "predictable." Meanwhile, both terms are used and intertwined, and neither approach is preferred. Bulatović [10] maintained that the point at which individual access yields a better value should be identified. However, Boer and van Engers [15] discussed the importance of agile implementation in public administration as an acceptable tool for change of regulatory policy and formulation of policy proposals in a multi-stakeholder environment. On the other hand, Simoyama et al. [16] presented the results obtained from the adaptation and implementation of Scrum as an agile project management tool in a government agency. They used Scrum to managing projects in a defined organization and discovered that agile approach improved the efficiency of the project deliverables without any loss in the quality of the intermediary and final products.

Basically, Scrum method is an iterative delivery of "potentially deliverable products." Meanwhile, interaction among participants, multiple iterations, and frequent testing lead to the delivery of better products [17]. According to the Agile Business Consortium [18], assigning clear roles and responsibilities to each person in an interdisciplinary project team is of great importance to the success of the project. However, the roles for satisfying business, technical, management and process requirements, and interests of the project are assigned to the project team members, based on Dynamic System Development Method (DSDM) method. It also emphasizes the importance of self-organizing teams that respect the knowledge, experience, skills, and opinions of other participants; and assume responsibility for their work and collaboration in the team. These principles agree with Scrum and can provide a positive synergistic effect if they are combined.

\section{AGILE BASED MANAGEMENT MODEL IN LOCAL SELF-GOVERNMENT UNITS}

\subsection{Present organization model}

In accordance with the legal obligations, the usual management and organizational structure of LSGUs is a functional type whose general form is shown in Figure 1. According to the Law, the City Council is a representative body that makes decisions, while the executive function is performed by elected mayors and their deputies. Meanwhile, administrative bodies (administrative departments and sections) are established to carry out tasks within their scope. 


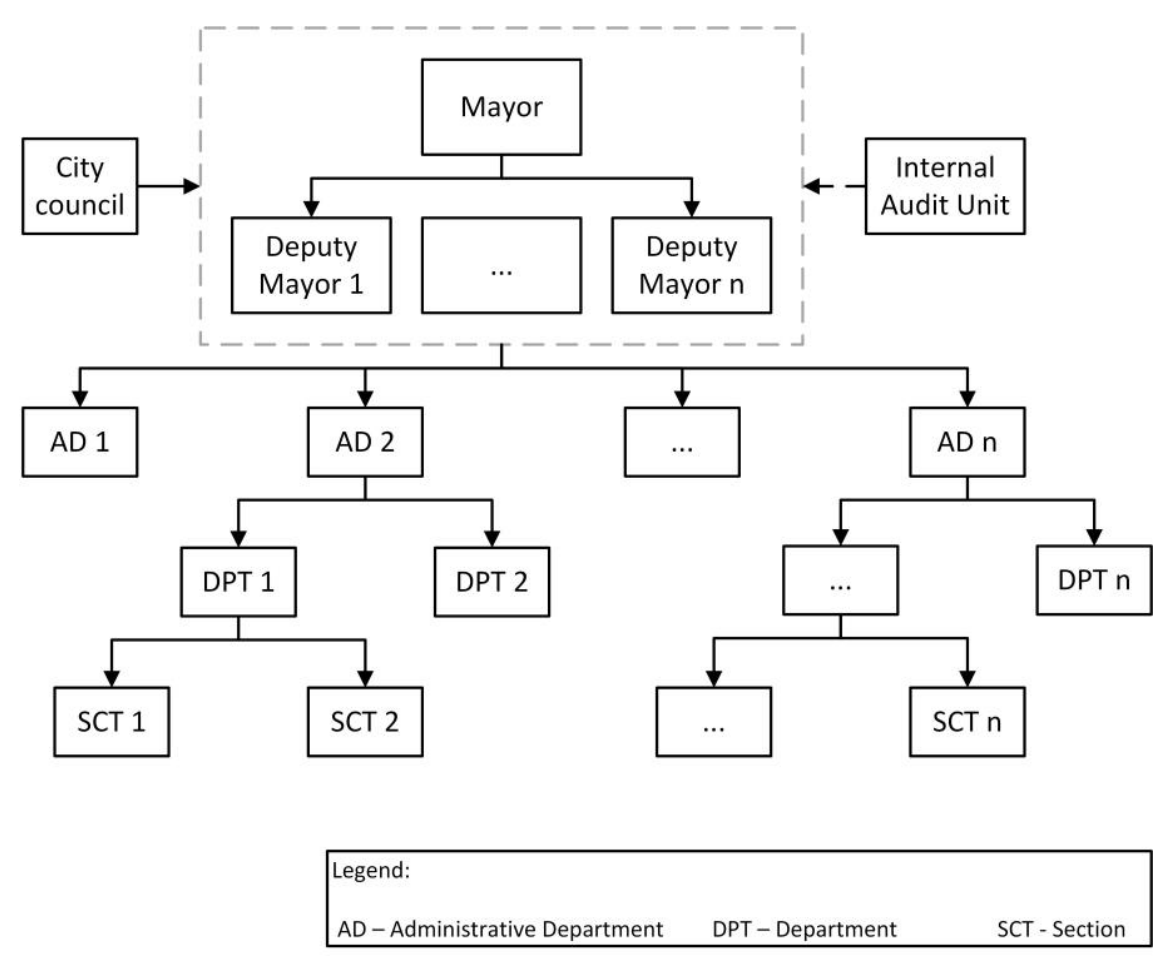

Figure 1 Present functional organizational structure in LSGUs

The aforementioned organizational form supports the execution of LSGU regular functional tasks. However, it has proved insufficiently flexible and inadequate to respond readily to the challenges of successful project realization in new, competitive, and project-based circumstances. These problems became important due to the accession of Croatia to the EU 2013, i.e. with the increased possibilities of withdrawal of funds from EU funds available for projects, especially construction projects. Apart from the impact on GDP growth, there was a strong impact on the ability to develop other economic sectors. This resulted in the adoption of the Act [12], which contributed to the creation of conditions for more efficient withdrawal of funds. Common ways to respond to these risks are by introducing more flexible organizational structures: project and matrix structures. However, due to the statutory legal framework, the introduction of such solutions in LSGUs requires increased attention and reexamination of opportunities and risks.

On the other hand, three problems based on Strategy 2015 - 2020 have been identified in LSGUs, which are a part of the public administration system. Meanwhile, the problems are related and should not be prioritized. Furthermore, their solutions must be approached systematically as partial solutions could highlight another problem.

Based on the aforementioned, problems in LSGU are grouped into three related entities:

- Communication problems - all communication problems within and between LSGU bodies and communication with users,

- Structural problems - issues related to the LSGU system, organizational structure, and authority,

- Competence problems - issues related to standardization of qualifications and professional development.

\subsection{Innovated organization model}

The basic idea is that LSGU project implementation could be significantly improved by introducing a matrix organizational structure supported by an agile framework in the implementation of business processes. The organizational and management basis is a matrix organizational structure that supports the fulfillment of mandatory legal functions within the existing departments. According to Joyce [19], the biggest advantage of matrix organizational structure is the formalization of lateral communication channels that improves the engagement of individuals within the organization. Thus, maintaining the basic existing structure is necessary due to legal 
provisions as it allows an uninterrupted continuation of present roles without major changes. However, employees usually find it difficult to adjust to large and sudden changes in their roles.

The proposed agile-based matrix organizational model is based on several organizational and functional solutions (Figure 2). The main basic proposed novelties and improvements integrated in the matrix organizational structure that refer to the LSGU project component are:

- Establishment of a new project management department (PMD),

- Licensed project managers in the PMD,

- Implementation of the agile principles in the project execution,

- Establishment of a procurement department (PD),

- $\quad$ Strengthening horizontal and lateral links between departments at project level.
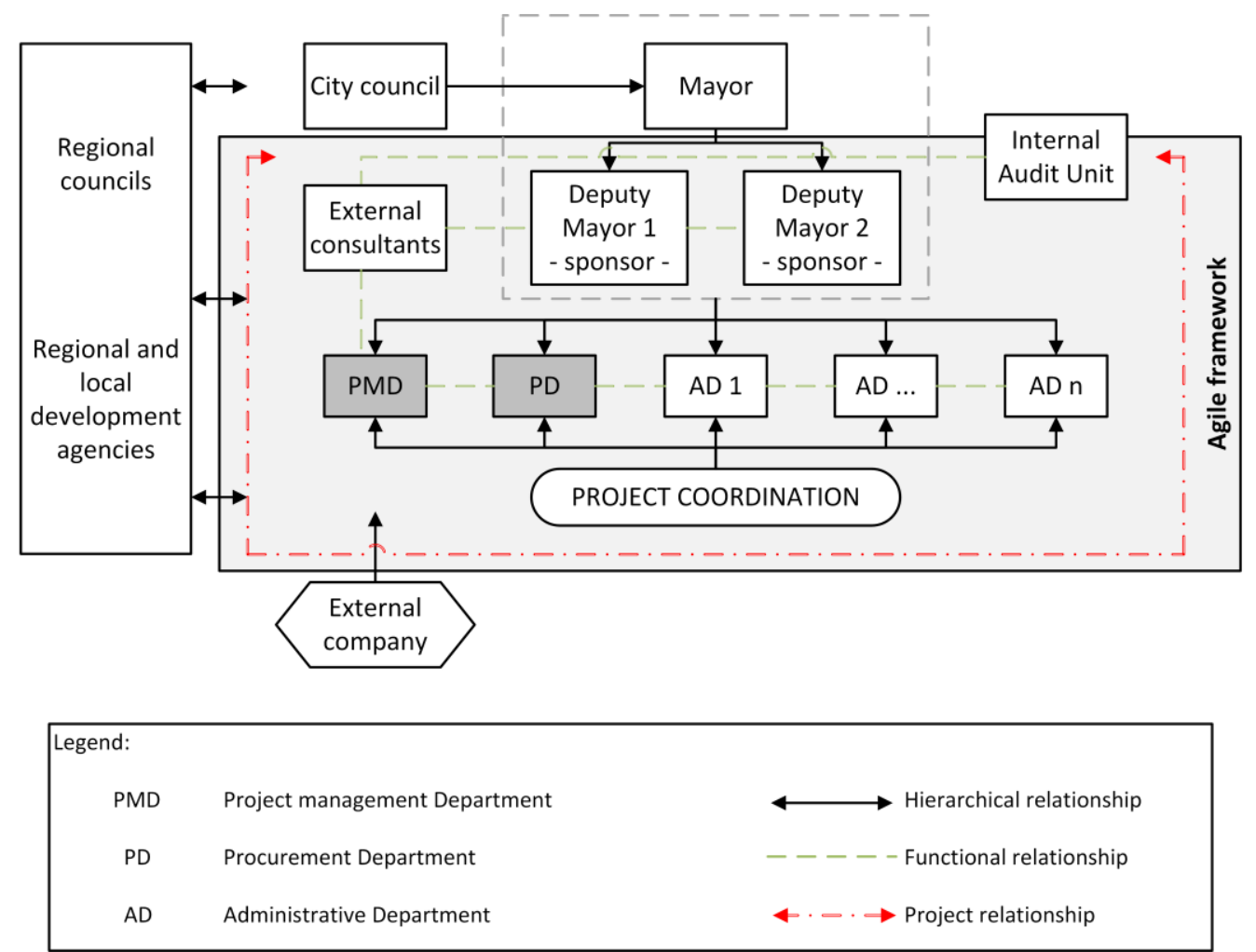

Figure 2 Agile-based matrix organizational model

Meanwhile, a well-organized system based on agile principles as well as change of organizational culture and financial motivation are of crucial importance while the agile framework supported by Scrum method is crucial in the project execution (Figure 2). Basically, Scrum method is an iterative delivery of "potentially deliverable products." Meanwhile, interaction among participants, multiple iterations, and frequent testing lead to the delivery of better products [17]. According to the Agile Business Consortium [18], assigning clear roles and responsibilities to each person in an interdisciplinary project team is of great importance to the success of the project. However, the roles for fulfilling business, technical, management and process requirements, and interests of the project are assigned to the project team members, based on Dynamic System Development Method (DSDM) method. It also emphasizes the importance of self-organizing teams that respect the knowledge, experience, skills, and opinions of other participants; and assume responsibility for their work and collaboration in the team. These principles agree with Scrum can provide a positive synergistic effect if they are combined.

Since construction projects are of special interest, financial resources for establishing this department should be considered. One option is to redistribute financial resources. The department would hire some licensed project managers of various levels of qualification. Meanwhile, the number and structure can be changed, based on the existing and planned number of projects. However, there are no plans for new employment as the existing staff would 
be reallocated and trained. The staff is responsible to the head of department who is a licensed senior project manager and projects are assigned to the managers based on complexity and field of expertise.

The project is assigned to the functional unit staff based on field of expertise. Moreover, the staff is responsible to the project manager. However, strengthening horizontal and lateral links between departments at project level as well as the other links is foreseen. This anticipates changing the existing awareness and organizational working culture within one's own organizational unit. However, the staff assigned to the project may perform only the project tasks rather than the usual functional tasks. This will be a less common solution due to insufficient staffing capacity. Meanwhile, the staff assigned to the project usually perform the functional tasks. Besides, the establishment of a procurement department is important for the project implementation and should thus be established in the LSGU as it conducts public procurement and low-value procurement.

On the other hand, the role of external consultants is multidisciplinary. One role is the counseling of project sponsors, managers and, if necessary, teams. The composition and structure of the consultant team are varied and depend on the project requirements and type.

Furthermore, specific projects include engagement of external companies. Therefore, specialized companies would be assigned some project work for which the LSGU do not have the appropriate personnel and other resources, through contract deals. Meanwhile, these proposed solutions require adequate financial sources. Thus, the managers need to find satisfactory legal solutions within the budget by redistributing funds. This is a very important element as financial motivation and support are essential factors of success. Hence, opportunities always exist, and solutions are discovered and applied, depending on the skillfulness and decision of the managers.

Regional councils and development agencies should be established based on the Law with the goal of improving regional development policy on the principles of partnership between regional and local units. The existing organizational conditions have not exhausted all the possibilities of the Councils for LSGU development. The aim is to exploit this possibility within the proposed improved model by strengthening the functional links. Moreover, local self-governments assess the justification and the need to establish a local development agency. Therefore, LSGU should actively cooperate with the regional development agency.

Thus, objective and subjective problems as well as difficulties in introducing the proposed agile-based matrix organizational model to LSGUs exist. This research indicates legal framework, finance, as well as organizational and management culture as key factors influencing the ability and success of the current implementation of the innovative model. Legal provisions generally do not allow additional employment and financial reward for employees engaged in additional work. These objective circumstances as well as existing management and organizational culture, which in some situations may indicate lack of knowledge and willingness to change, are the main obstacles to the implementation of an innovative model. Additionally, the following possible problems should also be highlighted:

- Lack of adequate project management knowledge at management and employee levels $[4,6,10,16]$,

- Existing organizational culture of working in closed units with weak lateral communication channels [1, 4, $9,10,16,20]$,

- Difficulties in employee adaptation to new business challenges $[4,6,10,15,20]$,

- Lack of experience in the multidisciplinary approach [1, 10],

- Procurement problems in the project implementation [1, 10, 16, 20],

To deal with aforementioned problems, a hybrid model has been proposed that enables the implementation of effective and innovative solutions within the existing legal and financial framework. In this context, the key elements are willingness and skill of management structures in implementing the proposed changes while motivating employees to accept these changes. An important measure is the spending of available financial resources based on the revised priority list in accordance with the requirements for model implementation, provision of additional funding for model implementation, and possibly using project funds to strengthen management and organizational culture through appropriate education, decisions, and behavior.

Hence, the following measures are proposed:

- Maintaining the basic existing structure that allows an uninterrupted continuation of present roles without major changes. It is expected that employees would adjust to such moderate organizational changes with less difficulties,

- Matrix organizational structure formalize lateral communication channels. Agile framework supported by Scrum method strengthen the lateral channels, 
- Intensive multidisciplinary approach in solving project problems,

- Establishment of procurement department,

- Continuous licensed project managers at different levels education.

Although the model has not been applied in Croatia, the results of this research, particularly the case study, indicate that possible problems with the proposed measures could be reduced to a level that would not jeopardize the implementation of the model. Meanwhile, good preparation (based on the elements indicated above) for the model application will be of benefit. On the other hand, a priori implementation in an unrealistic solution can cause more damage than good.

\section{DISCUSSION}

Based on the results above, agile-based matrix organizational model is suggested. The model integrates matrix organizational structure with agile framework by combining project and functional levels based on Scrum and DSDM methods. Thus, multiple iterations and frequent testing result in better delivery, using Scrum method for interaction among participants [17]. Moreover, assigning clear roles and responsibilities to each person in an interdisciplinary project team are very crucial to the success of the project [18]. On the other hand, the roles for fulfilling business, technical, management, and process requirements as well as project interests are assigned to the project team members, using DSDM method. Furthermore, self-organizing teams that respect the knowledge, experience, skills, and opinions of other participants as well as take responsibility for their work and collaboration in the team are of crucial importance in the success of the project. These principles agree with Scrum can provide a positive synergistic effect if they are combined.

In addition, all the negative circumstances identified in LSGU functional organizational structure expressed in project implementation phase would be resolved or significantly mitigated by applying the proposed model. Most especially, the lack of formal and actual lateral functional relationships between departments, difficulty in recruiting staff from the departments in the project teams and poor organization, insufficient dynamics and efficiency of work processes in the execution of project activities would be minimized. Under the current circumstances in the Republic of Croatia, model can be introduced within the scope of the applicable legal regulations with the foreseeably reasonable use of financial resources. Additionally, the phase incremental application of the proposed model with previous determination of the existing circumstances can be applied in other scenarios, thereby contributing to the effective implementation of public administration projects.

\section{CONCLUSIONS}

A number of problems exist in the functioning system of local and regional self-governments, and have been identified through practical experience and scientific research. In the Republic of Croatia, they are explicitly stated in the National Public Administration Development Strategy 2015-2020. However, these problems are expressed in several functioning segments including the professional project part, which is the subject of this research.

The research has shown that the existing functional organization of the system does not suit the project requirements, especially in circumstances where the number of projects are increased. Meanwhile, most of these projects are construction projects, i.e., communal infrastructure and social standard projects (infrastructure). These facts require changes in the organizational structure as well as in the approach to project management and work process organization. Meanwhile, the usual matrix structure, which is commonly applied in solving this problem, is not effective. In the conditions of withdrawal of significant available European funds, especially funds from the Regional Development Fund, present organizational structure could be an obstacle to further development. Therefore, the matrix structure could be significantly improved by organizing business processes based on the agile framework. 


\section{References}

[1] Public Administration Development Strategy for the period 2015 - 2020, Official Gazette NN 70/15, http://narodne-novine.nn.hr/clanci/sluzbeni/2015_06_70_1329.html, Accessed 22 March 2017

[2] Mao, P.; Li, S.; Ye, K.; Cai, H. 2017: A field theory based model for identifying the effect of organizational structure on the formation of organizational culture in construction projects. KSCE Journal of Civil Engineering, 21(1), pp. 45-53, https://doi.org/10.1007/s12205-016-1233-7

[3] Dobbs, R. et al. 2013: Infrastructure productivity: How to save \$1 trillion a year. The McKinsey Infrastructure Practice. The McKinsey Global Institute

[4] Bider, l.; Jalali, A. 2016: Agile business process development: why, how and when - applying Nonaka's theory of knowledge transformation to business process development. Information Systems and e-Business Management, 14(4), pp. 693-731, https://doi.org/10.1007/s10257-014-0256-1

[5] Nonaka, I. 1994: A dynamic theory of organizational knowledge creation. Organization Science, 5(1), pp. 1437, https://doi.org/10.1287/orsc.5.1.14

[6] Demir, S.T.; Theis, P. 2016: Agile design management, the application of scrum in the design phase of construction projects. 24th Annual Conference of the International Group for Lean Construction, Boston, USA, pp. 13-22.

[7] Project Management Institute: A guide to the project management body of knowledge (PMBOK), 5th ed., Newtown square: Project Management Institute, USA, 2013.

[8] Owen, R.; Koskela, L.J.; Henrich, G.; Codinhoto, R. 2006: Is agile project management applicable in construction. Proceedings for the 14th Annual Conference of the International Group for Lean Construction, Santiago, Chile, 2006, pp. 51-66.

[9] Torrecila-Salinas, C.; Sedeno, J.; Escalona, M.J.; Mejias, M. 2013: Agile in public administration: oxymoron or reality? An experience report. Proceedings of Industrial Track of the Conference on Advanced Information Systems Engineering, Valencia, Spain

[10] Bulatović, G. 2015. Implementation of the Hybrid Agile Organizational Structure in Local Government Units. Graduation thesis. Faculty of Civil Engineering, University of Rijeka, Rijeka

[11] Law on Local and Regional Self-Government, Official Gazette NN 19/13, http://narodnenovine.nn.hr/clanci/sluzbeni/2013 $02 \quad 19$ 323.html, Accessed 22 March 2017

[12] Regional Development Act of the Republic of Croatia, Official Gazette NN 147/14, http://narodnenovine.nn.hr/clanci/sluzbeni/2014 12 147 2751.html, Accessed 22 March 2017

[13] Agile Manifesto. 2001. http://agilemanifesto.org/, Accessed 12 February 2017

[14] Cobb, C. G. Making Sense of Agile Project Management: Balancing Control and Agility. Hoboken: John Wiley \& Sons, 2011.

[15] Boer, A.; van Engers, T. 2013: Agile: a problem-based model of regulatory policy making. Artificial Intelligence and Law, 21(4), pp. 399-423, https://doi.org/10.1007/s10506-013-9144-0

[16] Simoyama, F. de O.; Bueno, R.L.P.; Battisti, M.C.G. 2016: Adaptation and implementation of scrum methodology for agile projects in a government agency. Journal of Management \& Technology, 16(2), pp. 260-276, https://doi.org/10.20397/2177-6652/2016.v16i2.937

[17] Takeuchi, H.; Nonaka, I. 1986: The New Product Development Game. Harvard Business Review, pp. 137146.

[18] Agile Business Consortium, 2014.: The DSDM Agile Project Framework (2014 Onwards), https://www.agilebusiness.org/resources/dsdm-handbooks/the-dsdm-agile-project-framework-2014onwards, Accessed 13 March 2017

[19] Joyce, W. F. 1986: Matrix Organization: A Social Experiment. Academy of Management Journal, 29(3), pp. 536-561, https://doi/10.2307/256223 Accessed 13 March 2017

[20] Sy, T.; Beach, L.; D’Annunzio, L. S. 2005: Challenges and Strategies of Matrix Organizations. Human Resource Planning, 28(1), pp. 39-48.

Please cite this article as:

Car-Pušić, D.; Marović, I.; Bulatović, G.: Agile organization model for managing local government projects, Electronic Journal of the Faculty of Civil Engineering Osijek-e-GFOS, 2019, 18, pp. 12-21, https://doi.org/10.13167/2019.18.2 